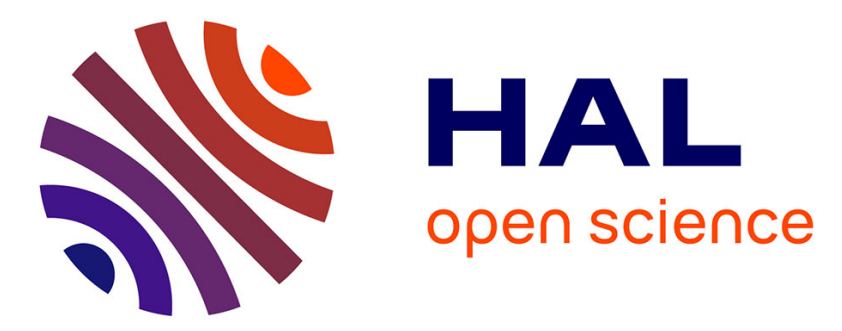

\title{
Ecodesign tools in the construction sector: analyzing usage inadequacies with designers' needs
}

\author{
Guillaume Lamé, Yann Leroy, Bernard Yannou
}

\section{To cite this version:}

Guillaume Lamé, Yann Leroy, Bernard Yannou. Ecodesign tools in the construction sector: analyzing usage inadequacies with designers' needs. Journal of Cleaner Production, 2017, 148, pp.60-72. 10.1016/j.jclepro.2017.01.173 . hal-01452620

\section{HAL Id: hal-01452620 \\ https://hal.science/hal-01452620}

Submitted on 2 Feb 2017

HAL is a multi-disciplinary open access archive for the deposit and dissemination of scientific research documents, whether they are published or not. The documents may come from teaching and research institutions in France or abroad, or from public or private research centers.
L'archive ouverte pluridisciplinaire HAL, est destinée au dépôt et à la diffusion de documents scientifiques de niveau recherche, publiés ou non, émanant des établissements d'enseignement et de recherche français ou étrangers, des laboratoires publics ou privés.

\section{(1) (1) $\$$}

Distributed under a Creative Commons Attribution - NonCommercial - NoDerivatives 44.0 


\title{
Ecodesign tools in the construction sector: analyzing usage inadequacies with designers' needs
}

\section{Supplementary files are provided at the end of the document, after the references.}

\section{Highlights}

- Current ecodesign tools fail to meet building designers' needs.

- Interviews lead to a model of usages, problems, and solutions in building ecodesign.

- The DSM Value Bucket algorithm analyzes the matching between tools and practice.

- Tools are missing in early stages, for multicriteria analysis and benchmarking.

- Conclusions are also drawn on the integration of the building design process.

\begin{abstract}
In this article, a usage-driven perspective is taken to analyze the lack of industrial uptake of ecodesign tools in the construction sector. Eleven interviews with professionals were carried out to gain insight into the building design process, the roles of the different actors and their interactions. Nineteen further interviews investigated ecodesign knowledge and practice, and the barriers to wider implementation of this approach. The data drawn from the interviews were analyzed with the Dependency Structure Modelling Value Bucket (DSM VB) algorithm. The algorithm maps usage situations, designer issues and existing ecodesign tools to highlight gaps in the available offer for ecodesign tools. It appears that ecodesign tools are missing in the early design stages, and that what is most needed in these phases are tools for multicriteria analysis (economic, social, and environmental) and benchmarking. Tools answering these needs, combined with desirable changes we identified in the design process, would help ecodesign adoption.
\end{abstract}

\section{Keywords}

Ecodesign, sustainable building, usage-driven design, building design, implementation, research-practice gap 
Accepted manuscript for: Lamé, Leroy, and Yannou. 2017. "Ecodesign Tools in the Construction Sector: Analyzing Usage Inadequacies with Designers' Needs." Journal of Cleaner Production. doi:10.1016/j.jclepro.2017.01.173.

\section{Introduction}

The construction sector plays a key role when environmental issues are under discussion, as buildings are major contributors to the environmental impact of human activity (Anderson et al., 2015). For instance, in France, tertiary and residential buildings accounted for $44 \%$ of final energy consumption in 2012 and 22\% of carbon dioxide emissions in 2011 (ADEME, 2013).

To address this issue and reduce the environmental impact of human-led activity, one possible solution is the integration of environmental aspects in product design and development, which is called ecodesign (ISO, 2002). Indeed, choices made during the design phase can have a major impact on the environmental performance of products (Jeswiet and Hauschild, 2005). Ecodesign covers a wide range of practices: methodologies, software, specific processes, etc. This article focuses on those practices that have been formalized and are referred to as ecodesign tools, namely "any systematic means for dealing with environmental issues during the product development process" (Baumann et al., 2002). In the construction sector, building ecodesign can be defined as "all tools minimizing the inherent environmental impact of a construction" (Gobin, 2011). Various issues are tackled, such as energy saving, human health or biodiversity protection (Peuportier et al., 2013), and ecodesigned buildings are sometimes referred to as "green buildings" (Wang et al., 2005).

Although many ecodesign tools have been produced since the emergence of the concept, evidence shows that ecodesign is still not widespread in industry. In the construction sector, researchers have investigated structural market characteristics which deter investors from supporting ecodesign (Häkkinen and Belloni, 2011; Persson and Grönkvist, 2014), and others have assessed and compared building certification systems (Ding, 2008; Suzer, 2015). Case studies of Life Cycle Assessment (LCA) used in building design have been reviewed (Cabeza et al., 2014; Ortiz et al., 2009). However, evidence is still missing on how ecodesign tools fit into designers' activities and why non-users, i.e. those who do not use ecodesign tools, do not adopt them. This is true for ecodesign in general, and even more for building ecodesign. Research on barriers to ecodesign tools implementation does underline high-level issues, but does not accurately pinpoint where and when tools would be useful for performing certain tasks during the building design process. Previous analysis has focused on the characteristics of the tools (cf. Reijnders and van Roekel, 1999 for example), rather than on their use by professionals. Moreover, most of the literature in the construction sector has addressed LCA and there is little study of the industrial uptake of other tools.

In this article, a user-centered perspective is taken to analyze barriers to ecodesign tool implementation. The objective is to analyze practices and to obtain feedback from users, in order to understand why ecodesign tools are not used more. A second part is to understand if unknown tools 
could provide functional answers to designers' problems, and what tools are still missing to alleviate these problems. To do so, practitioners are interviewed to understand the stages of the building design process in France and participants' roles concerning the environmental dimension. In a second interview phase, practitioners are asked about ecodesign tools and issues they encountered when trying to put ecodesign into practice. Then a tool - the DSM Value Bucket algorithm - is used to map the process stages, the ecodesign tools and the ecodesign issues in building so as to identify the areas where needs exist which are not being met.

\section{Literature review on the implementation of ecodesign tools in industrial practice}

\subsection{Implementation of ecodesign tools}

There are many tools intended to help designers improve environmental performance. By as early as 2002, more than 150 could be identified in the literature (Baumann et al., 2002). Ecodesign tools cover different aspects: Bovea and Pérez-Belis (2012) identified 35 tools for integrating environmental requirements into the product design process; Goodall et al. (2014) found 41 tools to evaluate remanufacturing feasibility. These figures show that numerous ecodesign tools exist.

However, despite the abundant options of available ecodesign tools, their implementation is still very limited. In a 2010 telephone survey of 373 French companies 33\% declared that they had implemented ecodesign practices, but only $20 \%$ had integrated ecodesign for all their products (BVA and ADEME, 2010). In a survey of 93 British companies, $43 \%$ declared to include environmental considerations "often" or "very often" during the design brief stage, $45 \%$ for functional requirement, $50 \%$ for conceptual design, $47 \%$ for embodiment design and $52 \%$ for detailed design (Deutz et al., 2013). In other surveys, out of 69 French companies, 44 had ecodesigned less than $20 \%$ of their products (Reyes, 2007), among 112 UK and Sweden manufacturing companies, less than 50\% declared to practice ecodesign (Short et al., 2012).

Although ecodesign is an important element in contemporary design strategies and design management (van Hemel and Cramer, 2002), it has not yet been generalized (Baumann et al., 2002; Bovea and Pérez-Belis, 2012; Vallet et al., 2013). Ecodesign is still in a propagation phase. In order to explain this situation, many authors have studied the barriers for ecodesign implementation.

Zhang et al. (2013) underline the fact that the literature does not provide "any clear example of a wide variety of tools (not only LCA) that could be used along the design process in a federative approach, nor the possible connections between the various product designers' activities and the 
various environmental tools". Bovea and Pérez-Belis (2012) propose that complexity, the time required for implementation and the lack of environmental knowledge are reasons for the low use of ecodesign tools. Le Pochat et al. (2007) identify the difficulty of use and the lack of interoperability as major barriers for implementing ecodesign tools. Lindahl (2006) also observed a lack of follow-up on implementation from managers as an explanation for low use. Lofthouse (2006) concludes from an industrial case study that the language used in ecodesign tools is not adequate, that tools are timeconsuming and separate from regular design practice.

Bey et al. (2013) identified four main barriers: finding environmental information; no extra resource allocated; too much expert knowledge required; and the difficulty of identifying suitable alternatives for components or materials. Birch et al. (2012) compared 22 tools and concluded that most tools focus more on product strategy than on operational design tasks. Poulikidou et al. (2014) conclude that tools are either too simple or too advanced, and often unfit for designers, while also mentioning cooperation obstacles, communication difficulties and difficulties to access information as barriers. Finally, some authors (Lindahl, 2006; Millet et al., 2007) identified a well-diffused tool, LCA, as unfit for design purpose.

It should be noticed that many of these barriers stem from root causes identified by Lofthouse (2006) and Lindahl (2006): an insufficient analysis of both the requirements of designers and of the design context results in a misalignment between tools and designers' needs and practices.

\subsection{Situation in the construction sector: implementation of building ecodesign}

Building ecodesign covers a wide range of objectives and practices, e.g. construction waste reduction by design (Osmani et al., 2008), the use of recycled materials (Chick and Micklethwaite, 2004) and energy-efficient building design (Attia et al., 2012) . To achieve such objectives, tools are numerous. Already in 2004, IEA Annex 31 counted 133 tools of different sorts in 14 countries (IEA Annex 31, 2004), with many LCA tools, but also checklists, design guidelines and rating systems. Examples of tools used for building ecodesign are LCA (Ortiz et al., 2009), Material Flow Analysis (Rincón et al., 2013) or assessment frameworks (Ding, 2008). However, the construction sector does not appear to be different from other sectors when it comes to ecodesign implementation in everyday business practice. The literature on the subject is limited and mainly addresses LCA implementation, which is likely due to the fact that certifications schemes include LCA or will include it soon, e.g. LEED 4.0 (Olinzock et al., 2015), or because LCA can help to ensure compliance with energy regulations (Malmqvist et al., 2011). 
Despite these motivators, in interviews with construction experts, Leroy et al. (2013) found that LCA was rarely performed. In the questionnaire survey by Olinzock et al. (2015), 54\% of the 179 respondents had never used LCA. In a recent literature survey, Cabez et al. (2014) found that most LCA papers look at "exemplary buildings", i.e. buildings that were planned to have high environmentally performance. Barriers to a wider implementation of LCA in the construction sector can be sorted into two categories: firstly, the lack of data, cost and complexity of LCA (Cooper and Fava, 2008; Olinzock et al., 2015; Saunders et al., 2013; Scheuer et al., 2003). Secondly, the lack of customer demand and government incentives (Olinzock et al., 2015; Saunders et al., 2013).

Besides LCA, assessment frameworks like BREEAM and LEED are widespread (Ding, 2008; Zuo and Zhao, 2014). These frameworks assess the building's performance in terms of its environmental impact, and sometimes its social and economic dimensions. However, Ding (2008) questions the adequacy of environmental assessment frameworks as design support tools. In the same spirit, Zuo and Zhang (2014) use assessment frameworks as a defining feature of green buildings rather than as a tool to design sustainable buildings. In what follows, we do not consider assessment frameworks as ecodesign tools because they evaluate complete designs rather than help designers during the design process. However, design guidelines written to help designers comply with assessment frameworks can be considered as ecodesign tools.

Design tools such as Computer-Assisted Drawing (CAD) software or Building Performance Simulation (BPS) software are also not included in our scope of ecodesign tools. Although these tools are indispensable in building design, and are very popular (Attia et al. (2011) count no less than 389 tools for BPS), they do not have a specific environmental orientation and therefore leave responsibility to the user when applying them for environmental purposes. This choice is in line with the ecodesign literature which usually does not include mainstream $C A D$ and simulation tools.

\subsection{Issues addressed in this paper}

A reason regularly identified for the lack of implementation of ecodesign tools is the inadequacy between proposed ecodesign tools and designers' needs (Lindahl, 2006; Lofthouse, 2006; Millet et al., 2007). Research may have its share of responsibility in this result. Indeed, many papers presenting ecodesign tools fail to mention implementation. Only 122 of the 339 papers on ecodesign tools analyzed by Baumann et al. (2002) are "empirical", as opposed to "conceptual". In those articles, "empirical material is presented, but often as an illustration rather than as a testing ground for the hypotheses". Baumann et al. (2002) conclude that there is "too much tool development" and that "those involved in the field are more interested in developing a new tool than on studying the use of existing ones and to evaluate them in order to improve them"-a classic issue in design 
Accepted manuscript for: Lamé, Leroy, and Yannou. 2017. "Ecodesign Tools in the Construction Sector: Analyzing Usage Inadequacies with Designers' Needs." Journal of Cleaner Production. doi:10.1016/j.jclepro.2017.01.173.

research (Blessing and Chakrabarti, 2009). As a result, many ecodesign tools do not meet designers' expectations and are not used.

To fill this gap between research and practice, new approaches are needed to identify designers' needs for ecodesign tools. Once the needs of designers are known, existing tools can be adapted or hybridized, or new tools can be developed. This is particularly interesting in the construction sector, where LCA appears to be the only well-known ecodesign tool. More knowledge on the needs of building designers could allow the adaptation of ecodesign tools from other sectors to the construction sector.

Therefore, this paper addresses the following questions:

1. What are the barriers for ecodesign tool implementation in the building sector? What are the current ecodesign practices?

2. How well do existing ecodesign tools meet designers' needs?

3. Which developments would have the most impact for designers?

To answer these questions, we undertake a qualitative descriptive study in the French construction sector. Two phases of interviews (thirty people in total) are carried out with professionals. In the first phase, the objective is to understand practices during building design: process steps, roles and interactions between actors. The second phase focuses on ecodesign: is it implemented and how, and how much do professionals know about ecodesign tools. We use an algorithm drawn from a usage-driven innovation methodology to analyze the results of the interviews and identify in which situations new ecodesign tools would provide the most value for designers.

\section{Methods}

\subsection{Research framework}

The literature review shows that ecodesign tools are often not fit for designers' usages. In recent years, a research stream has developed around usage-driven design. One specific application and embodiment of usage-driven design is the Radical Innovation Design ${ }^{\circledR}$ (RID) methodology developed by Yannou et al. (Yannou, 2015; Yannou et al., 2013). RID has proved its efficiency and robustness in a wide range of sectors, e.g. automotive suppliers, the pharmaceutical industry, healthcare IT solutions or robotics, see (Yannou et al., 2013) for examples. RID has two stages: Problem Design and Solution Design. As our interest lies in understanding why tools are not implemented and which gaps exist in the offer for ecodesign tools, we focus on the Problem Design stage. 
In the RID methodology, usages are analyzed to identify value buckets, i.e. important usage situations where major problems occur and for which few or no existing solutions are useful or efficient. To detect value buckets that need addressing in innovative solutions, an algorithm is proposed based on Dependency Structure Modelling (DSM) (Browning, 2001): the DSM Value Bucket (DSM VB) tool (Yannou et al., 2016). The DSM VB uses matrices across three domains: a solutions domain, a problems domain and a usage situations domain. These three domains are mapped oneto-one to populate three matrices (fig. 1):

- Matrix A represents how often problems occur in usage situations. It is called the "ideal performances" matrix

- Matrix B represents how solutions are relevant with regards to problems

- Matrix $\mathrm{C}$ represents how solutions are relevant with regards to usage situations
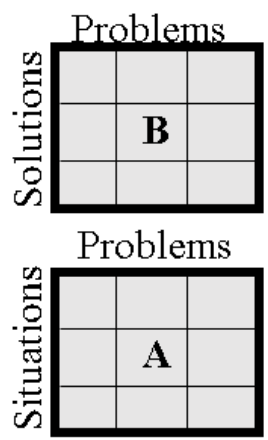

Solutions

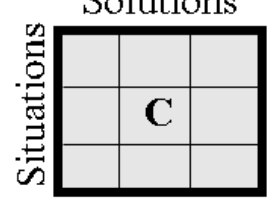

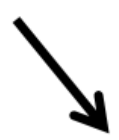
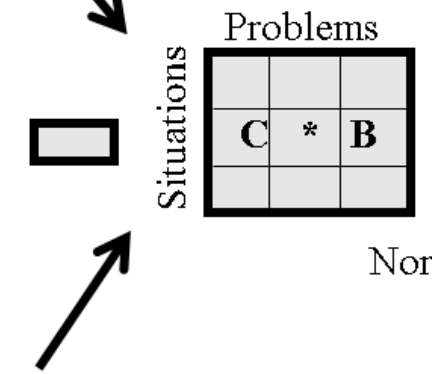

Normalization

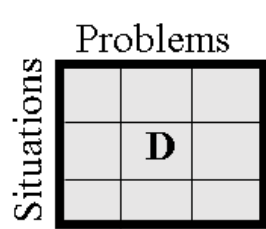

Weighting of problems and situations

Figure 1 - DSM Value Bucket tool data flow, adapted from (Yannou et al., 2016)

By multiplying matrices $C$ and $B$, the way current solutions usually tackle specific problems in specific situations is assessed. Matrix $C^{*} B$ therefore shows the average performance of available solutions. By normalizing matrices $A$ and $C * B$, and then subtracting $C^{*} B$ from $A$, actual issues in situations are compared to how well available solutions solve them. As a consequence, matrix $D=A-C^{*} B$ shows the gap between the actual issues and the remaining issues after available solutions have been applied. The bigger the gap, the less effective the available solutions. As all problems are not equally important and usage situations are not equally frequent, both dimensions are weighted to obtain the value buckets which are displayed as the highest values in matrix E. Value buckets are areas in the space of user situations where current tools do not address problems properly. Therefore, in these areas, there is a potential to create value for users. The content of the algorithm is presented in more details in Section 5. 
To apply this approach to building ecodesign tools, three sets of information are needed:

- Existing solutions (ecodesign tools which are or could be used for building design)

- Problems experienced by building designers

- Usage situations that designers experience.

A methodological framework is proposed to acquire this knowledge (fig. 2). Existing solutions are reviewed from the literature. Usage situations are drawn from a first interview phase and two case studies. Problems arise from the literature review, from interviews with professionals and from two case studies.

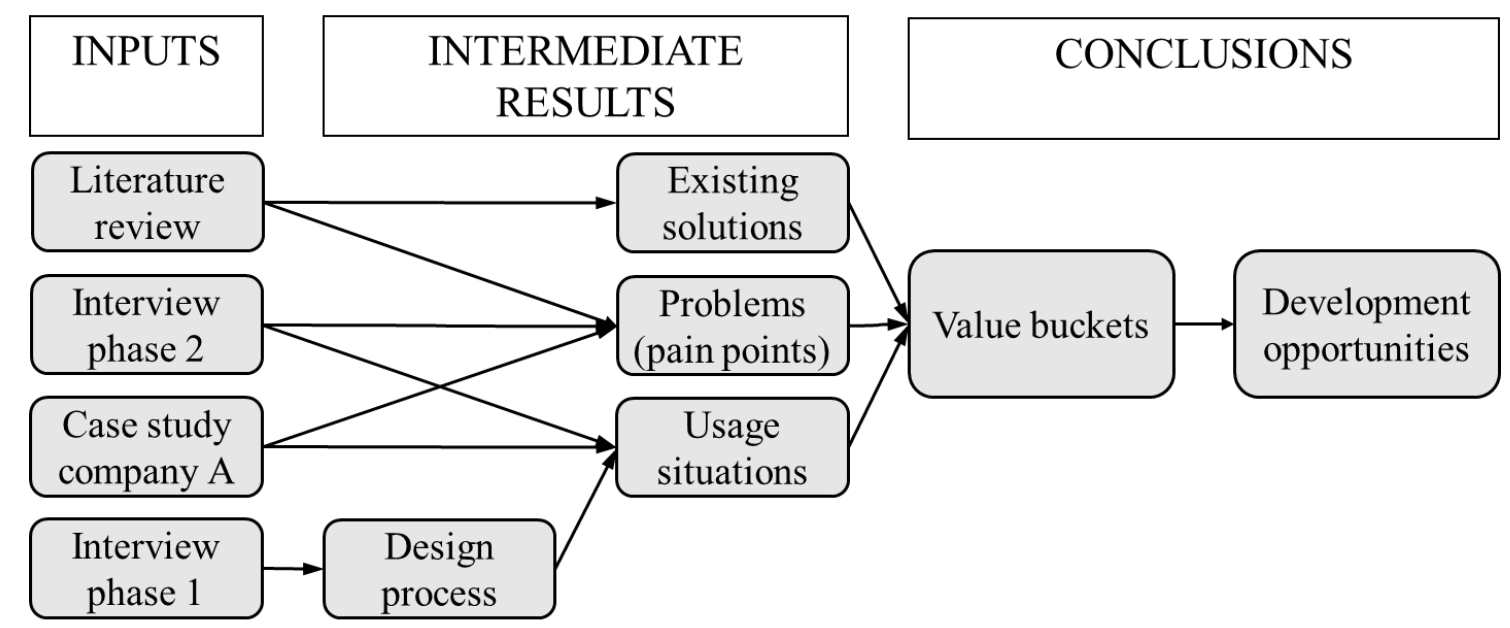

Figure 2 - Research framework

\subsection{Data collection}

\section{Interview phase 1}

This first phase of interviews is mainly exploratory. The objectives are to map the current building design process, to understand who the actors in this process are, how they interact, and what the main decisions are. Eleven experts were interviewed, either by phone or face-to-face. Some interviews involved multiple interviewees, and were therefore closer to a focus group approach. We provide a supplementary file with details on the profiles of the interviewees.

After these eleven people were interviewed, two additional interviews ( 2 hours and then 1 hour) were carried out with interviewee number 1 (an expert with 30 years of professional experience in the French construction sector) to validate the process map extracted from the other interviews. All interviews were semi-structured (Blessing and Chakrabarti, 2009): open questions had been prepared but the interviewees were free to go beyond this frame. 
Accepted manuscript for: Lamé, Leroy, and Yannou. 2017. "Ecodesign Tools in the Construction Sector: Analyzing Usage Inadequacies with Designers' Needs." Journal of Cleaner Production. doi:10.1016/j.jclepro.2017.01.173.

\section{Interview phase 2}

In this phase, we focus on the environmental dimension in the design process. The objective is to identify current ecodesign practices and barriers preventing practitioners from going further. The role of each actor in the integration of environmental aspects is investigated. The way information on the environmental dimension of the project is shared among actors is also established. Nineteen professionals and researchers took part in semi-structured interviews. The profiles of the interviewees are described in Supplementary file 1 on the electronic version of this article. Two interviewees had already participated in phase 1 (interviewees number 7 and 15). The panel includes all types of actors in building design projects. Twelve interviewees have an engineering background, three interviewees had a mixed architecture-engineering background, and four were trained as architects. The first interviewees came from the authors' network, while the next interviewees were contacted by "snowball sampling" (one interviewee giving the contact of the next one).

Questions were adapted depending on the profile of the interviewee, but the same general structure was kept. Interviewees generally extended the discussion far beyond the scope and the questions of the interview script, which was oriented towards the sketches stage. The script is provided as a companion to the electronic version of this article (Supplementary file 1). It starts with a presentation of the interviewee, their company and their projects. The second part focuses on the building design process, in order to map the flows of environmental information. Then the role of the interviewee during early design phases is investigated in greater depth. The third part consists of thematic subjects. First, users' involvement during design stages is discussed, because user-centered design is considered a promising approach for sustainable design (Wever et al., 2008). Next questions are about ecodesign tools. LCA receives special attention, because the literature review and preliminary discussions with professionals showed that it is the most recognized tool in the construction industry. The use of Building Information Models (BIM) is also discussed. BIM is a collaborative 3D computerassisted way to design buildings which might disrupt building design organization (Bryde et al., 2013; Succar, 2009). The interview concludes on the topic of management of ecodesign knowledge and environmental knowledge created during projects.

\section{Embedded case studies of projects $A$ and $B$}

To obtain more precise and specific data about usage situations and problems, a case study concerning two specific projects was also undertaken. The company is a French promoter, active in office, residential and commercial buildings, with around 1,500 employees and a turnover of approximately 2.5 billion euros per year. The choice of the company was opportunistic as one of its employees had been interviewed during the second phase of interviews. It presents sustainable design as a key element of its strategy. Historically, it started with carbon accounting. It then 
considered impact transfers, turning to life cycle analysis. It has launched pilot programs in building rehabilitation and passive buildings. Two projects were selected in this company, both of which are office buildings. One was started in 2010 and delivery was originally planned for the end of 2014. The other project was in design at the time of the study. This configuration allowed the association of feedback on the first project and live data on the second. Both projects were followed by the same environmental consultancy.

\section{Results}

\subsection{Building design process in France}

The first result, drawn from interview phase 1, is an understanding of the building life-cycle and the stages of the design process in France (fig. 3).

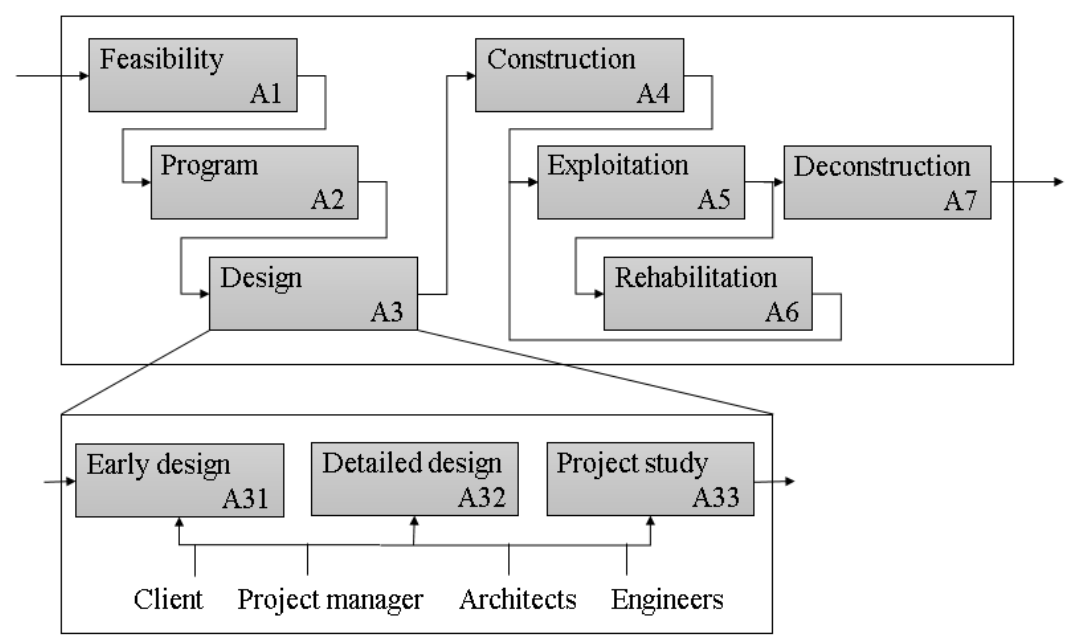

Figure 3 - SADT (Structural Analysis and Design Technique) model of the building life-cycle

The vocabulary used by construction professionals can be tricky: for them, "design" starts after the program phase has been completed. However, the program phase consists in specifying the requirements that will enable the building to be designed: it is considered a design activity in Pahl and Beitz's systematic design framework (Pahl and Beitz, 1996) and in INCOSE's system design method (Walden et al., 2015). This article considers all stages prior to the construction phase as design stages.

The interviews clearly showed that building design in France is organized sequentially. Several main steps are separated by major deliverables. These deliverables lead to decisions being made. The first one is taken at the end of the program stage. A document listing functional specifications and performance objectives is edited (called "programme" in French). Then, during early design, 
architects generate sketches. At the end of early design, project managers choose one sketch to be developed for the rest of the project (possibly from amongst proposals by different architects). During detailed design, concepts for structure, facade and HVAC system (Heating, Ventilation and Air Conditioning) are tested, which leads to a decision is made on a concept for structure, facade and HVAC system. During the project study, decisions are made about finishing touches: materials for doors, wallpapers carpets, etc.

The composition of the project team varies during this process. For the feasibility study and the program stage, the developer works with her assistants. After this "program" phase, the architect and the engineers are selected. Following the design phase, the building contractors are selected. In this configuration, architects are not present during the program phase, and contractors are absent during the design phase. Co-definition of requirements between customer and designer, and concurrent engineering between designers and contractors are impossible. Although alternative process configurations exist, this process is mandatory for all public projects in France. According to the interviewees, the same process is used in most private projects, and the emergence of environmental considerations has not modified this structure.

\subsection{The environmental dimension during building design}

To complete the activity-based view in Figure 3, interview phase 2 provided a model of how actors communicate about environmental aspects (Figure 4). In this model, the design team is composed of the architect team and the engineering consultancies.

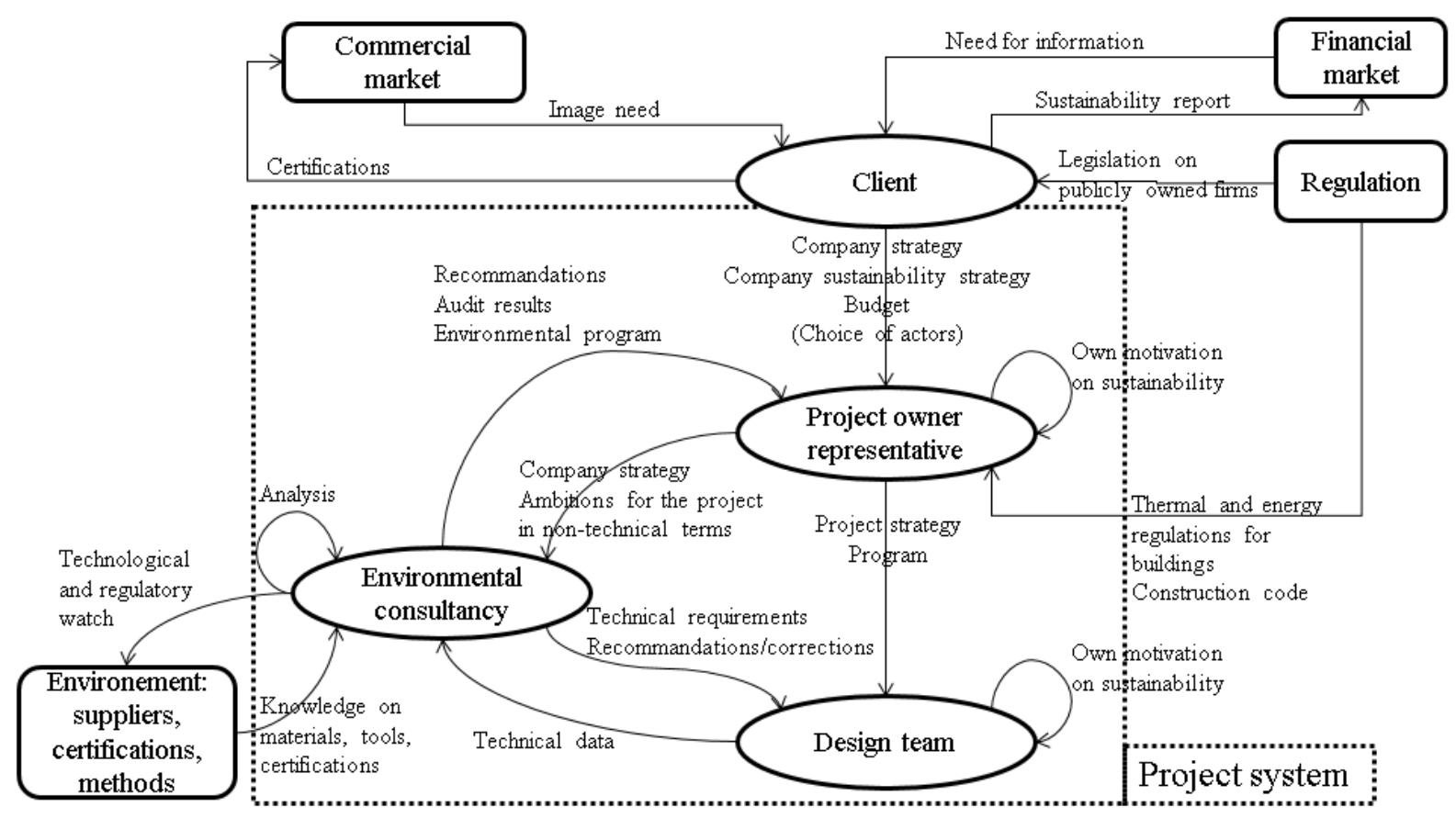

Figure 4 - Information exchanges on environmental aspects during building design 
Accepted manuscript for: Lamé, Leroy, and Yannou. 2017. "Ecodesign Tools in the Construction Sector: Analyzing Usage Inadequacies with Designers' Needs." Journal of Cleaner Production. doi:10.1016/j.jclepro.2017.01.173.

Concerning the environmental dimension during the building design process, four important elements were identified during interview phase 2.

\section{Central role of the environmental consultancy}

The environmental consultancy is the only actor with a global view of environmental stakes of the work of all design team members (architects, structural engineers, HVAC engineers, power engineers, etc.). The environmental consultancy is in charge of translating these technical elements into analysis and recommendations that are easily understandable by the client, often related to certifications. Design team members communicate on technical elements (power consumption, sun exposure, etc.), but the interpretation of this data in environmental terms is performed by the environmental consultancy.

\section{Importance of the extended project context}

The client is a representative of her company: she is responsible for managing costs, quality and delays. However, not all companies allow the same amount of freedom to these representatives: factors such as company culture, project value, importance of the project to company image, will have an impact. This can be expressed in terms of budget variations or imposed selection of key players, for instance. As a consequence, constrained budgets may push designers towards low-cost solutions, and some key project actors may be imposed to be people with limited knowledge, experience or interest in environmental issues. This shows the need to include an organizational, company-centered perspective and not only a technical, project-based one.

\section{Motivational aspects}

Several interviewees mentioned the fact that the project can only attain its highest sustainability level if all actors work with this objective in mind. Although legislation is pushing in this direction, not all professionals are yet fully convinced. To quote one interviewee, "the project will only be as environmentally good as the motivation of the least motivated member". The selection of project members is crucial here.

\section{Difference between SMEs and bigger companies}

This difference is classic in ecodesign (Buckingham et al., 2014). It concerns both resources and stakes. Concerning resources, all big companies interviewed had a "sustainability" department or an "environment" team. The organizational structures varied but permanent resources were allocated to environmental questions, including ecodesign (with varying maturity levels). These departments investigated new certifications, new methodologies and innovative materials. Small firms did not have such resources. Concerning stakes, publicly owned companies in France are obliged by law to issue a sustainability report every year. This can have impact on investors' behavior and is one of the bases for extra-financial notation. Consequently, these companies have to show initiatives and 
results to maintain their corporate image, including towards financial markets. This is not the case for SMEs, where this initiative is more closely related to management motivation.

The three last factors - extended project context, motivational aspects and company size - show the diversity of the construction sector. Therefore, in what follows, the structure of the design process, which is stable across the sector, can be used when a constant reference point is needed.

\subsection{Barriers and opportunities for ecodesign tool implementation}

Although everyone interviewed claimed to take the environment into account in their projects, the range of practices is very wide. It goes from limited adaptation of usual practices and emphasis on certain criteria (e.g. work on architectural compactness for architects) to the introduction of new tools in the design process (e.g. an environmental management system based on custom-made spreadsheets for decision traceability, or databases on innovative materials). Overall, knowledge of tools and of their application is limited. All interviewees were familiar with the French certification scheme HQE, although one of them declared that he did not apply for the certification for his projects and used it only as a guideline. The others generally applied for the certification for their projects. On occasions they did not ask for the certification because it required a lot of paperwork or because it constrained design too much. All but two interviewees knew LCA at least by name. This was the only ecodesign tool they could mention.

This raises a question: why are all other ecodesign tools so poorly known? The transfer of knowledge from academia to industry is a recurring issue in all domains. However, in France, today, ecodesign is a well-communicated subject. Books on building ecodesign (Menet and Gruescu, 2014), studies by various agencies (AFNOR and ADEME, 2008), technical sheets in widespread engineering encyclopedias (Janin and Bellini, 2011) offer a panorama of ecodesign tools such as LCA, Eco-Design Pilot and checklists and are easily found on the internet. We propose three tentative explanations for the weak knowledge of ecodesign tools in the construction sector.

Firstly, there is a strong feeling among the people we interviewed that all construction projects are different and therefore standardized methods are less adequate than in mass manufacturing industries. Indeed we heard many times in our interviews that the construction sector is, allegedly, "not like the industry". This could prevent building designers from investigating methods developed for a wide range of applications, and not specifically aimed at the construction sctor. Specific communication, from professional organizations for instance, could help with this.

Secondly, our interviews also suggest a reactive rather than proactive culture among construction professionals, triggered by regulatory evolutions. We have already mentioned that LCA is more and 
Accepted manuscript for: Lamé, Leroy, and Yannou. 2017. "Ecodesign Tools in the Construction Sector: Analyzing Usage Inadequacies with Designers' Needs." Journal of Cleaner Production. doi:10.1016/j.jclepro.2017.01.173.

more included in certifications and regulations, thus the overwhelming attention given to LCA at the expense of other tools. All interviewees seemed influenced by the HQE assessment framework, and those working in bigger companies or in environmental consultancies also mentioned BREEAM and LEED. New auditing schemes could shift the trend towards a more diverse toolbox.

Thirdly, we can suppose that those who tried the aforementioned tools did not perceive them as useful. Following Everett Rogers' model of the diffusion of innovations (2003), early adopters need to find an advantage in a new product to start using it and launch a trend. The literature review showed that ecodesign tools are often perceived as unfitted to designers' needs. Here the issue comes from the tools themselves, as they result in an insufficient toolbox to address the challenge of ecodesign. Whilst the two previous points called for cultural or regulatory action, in this case we need to identify what are the unresolved issues from adopting ecodesign tools. This is the objective of the DSM Value Bucket analysis performed in Section 5.

\section{Opportunities and barriers for LCA deployment}

Even if most interviewees knew about LCA, few of them had put it into practice. When we asked interviewees why they did not use LCA more, two types of barriers were identified: implementation and communication.

Implementation barriers are the problems faced when trying to conduct LCA in a design process. The first implementation barrier is that LCA comes too late. LCA is suitable for evaluating completely defined products, at the end of the design process, but at this stage modifying the product is too costly (Millet et al., 2007). The second implementation barrier is the difficulty of obtaining data. LCA requires a lot of data on materials and this data can be hard to come by (Reap et al., 2008a). In France, since 2014, industrialists who wish to communicate on the environmental qualities of their products need to produce an Environmental Product Declaration (FDES in French) and input it into a central database called INIES (Passer et al., 2015). However, according to interviewee \#19 smaller companies do not all have the resources or the ambition to take these steps. Therefore, one concern for the interviewees (\#1 and \#19) is that "innovative" products (bio-sourced products for instance) often do not appear in LCA databases. Third, the fact that results vary from one software and one database to another deters professionals from using LCA. This variation in the results has been evidenced by Takano et al. (2014). Confidence in LCA is limited due to these variations, which also generates indecision on which LCA software to choose. The final implementation barrier is economic: LCA is perceived as expensive compared to the benefit it brings.

Communication barriers are those which prevent the exploitation of LCA results either within or outside the company. The first communication barrier is the lack of demand: the value of LCA is not 
clearly perceived, as customers do not ask for it. Secondly, LCA is not included in certifications, or it does not give enough points. Thirdly, there is no reference to which projects can be compared. This makes it tough to evaluate whether a project is "doing well" or should be improved. It is therefore difficult to communicate inside the company and to clients. Fourthly, LCA methods give no priorities between impact categories. People do not know which impact category should be improved as a priority. Moreover, important sustainability issues are not included. Urban local biodiversity and internal air quality are emerging concerns which are not addressed by LCA. Finally, not all software are compatible with all certification frameworks, e.g. French certification HQE and British certification BREEAM. These communication barriers show the importance of certifications and commercial differentiation. As long as LCA does not provide a clear opportunity to communicate, these barriers will remain.

Motivation for conducting LCA is mostly prospective. Opportunities that actors are aware of include providing for future evolutions in regulation or certification. It is also performed to develop simple, heuristic, decision-aiding methodologies. Finally, LCA is considered as offering differentiating information to customers, as noticed previously by Leroy et al. (2013).

\section{Opportunities and barriers for BIM deployment}

All interviewees were aware of BIM and enthusiastic about its potential, but only one could mention a project where it had been implemented. The project was very complex and involved cross-Atlantic collaboration between architects.

The first benefit expected from BIM deployment lay in easier data sharing during design, which could solve data issues for LCA. Second, maintenance and exploitation would be made easier if accurate drawings were always available and shared between partners. Finally, BIM is expected to increase productivity in production. However, lack of training, especially in SMEs, and the absence of a common method is preventing the adoption of BIM for regular projects.

\section{Current practices and tools}

Currently, ecodesign is based on "classic" building design tools such as solar simulation, wind simulation, or building energy simulation. Rules-of-thumb are applied on parameters such as orientation and then simulated. Such approaches do not take a lifecycle perspective on the environmental impact of the building, which is a distinctive aspect of ecodesign. They ignore some dimensions of environmental impact (for instance toxicity, water consumption, or energy required to produce the materials) to focus mainly on energy consumption during the use-phase. Indeed, increasing effort is being expended on energy issues as Energy Performance Contracts become more frequent. In these contracts, designers and contractors commit to a certain energy consumption for 
the building they are delivering. Some emerging concerns are also becoming apparent, such as urban biodiversity. In addition to energy-related tools, private databases are built to cope with the missing products in national databases. Three interviewees mentioned such databases (interviewees \#1, \#15 and \#19). Besides, most companies use their own project environmental management tools. These are spreadsheet-based. These tools were mentioned in two interviews (interviewees \#1 and \#16).

\section{Data treatment - DSM Value Bucket analysis}

Having presented the results of the data acquisition phase, we now present an analysis of these results using the DSM VB tool.

Seven problems have been extracted from the list of issues reported in Section 4.2. This is because they were the most frequent, shared by at least two interviewees. These issues are problems experienced by practitioners when trying to practice ecodesign and to monitor, manage and reduce the environmental impact of the buildings they design. The seven problems are:

- Low level of environmental data: this occurs when not much is known about the components or the usage, or the data is mainly qualitative

- Low level of technical data: for example, drawings are not available for the analysis

- Difficulty to compare the environmental impact to other criteria: such as investment cost, maintenance cost, ease of maintenance, or functional aspects

- Difficulty to position the project: this is when a project is analyzed but it is difficult to say if the project's performance is "good" or "average" or "poor"

- Cost of analysis is too high: because existing methods are too expensive

- Delay of analysis is too high: when existing methods take too long compared to the lifecycle of the project

- Difficulty to compare options: when multiple criteria need to be considered and no priorities are set, or when the analysis carried is not able to differentiate options for instance.

Given the wide scope of the study, our usage situations are less specific than what is usual in RID. Following the Decision-Based Design paradigm (Hazelrigg, 1998), the usage situations follow the main decision stages of the design process. They concern the environmentally conscious design and choice of Program, i.e. the requirements for the building to be designed; Sketches, when an architectural concept is chosen from proposals made by different architects; Structure: wood, steel, concrete; Façade concept, when the concept (using a double-skin façade for example) and the materials (wood, steel, glass, concrete) for the façade are selected; HVAC (Heating, Ventilation and 
Air Conditioning) system architecture, when the structure and technology for HVAC (centralized or decentralized, gas or electric, etc.) is chosen; and Finishing touches, i.e. when internal elements like doors, wallpapers or carpeting materials are selected. "Environmentally conscious design and choice" means an informed decision, including explicitly the environmental impact as a criterion, even if the best option from an environmental point of view is not ultimately chosen.

Finally, six tools have been selected for analysis:

- Complete LCA (ISO, 2006; The EeBGuide Project, 2012), the classic LCA including all materials and flows during the whole lifecycle of the building

- Screening LCA (The EeBGuide Project, 2012), a simplified LCA for early stages, "usually performed using readily accessible data" (Moberg et al., 2010), and focused on known main contributors

- Quality Function Deployment for Environment (QFDE) (Masui et al., 2003), a modified QFD methodology including environmental aspects. QFD has been applied for green building design (Gillis and Cudney, 2014; Wood et al., 2016)

- Ecodesign Pilot (Vienna TU, Institute for Engineering Design, 2012; Wimmer and Züst, 2001), a generic tool to identify ecodesign strategies using checklists

- A guide by the reference French institute on building sustainability (Nibel and Valicourt, 2012). This is a step-by-step guide for the management of the sustainability aspects of a construction project

- "Evaluation simplifiée et qualitative du cycle de vie" (simplified and qualitative life-cycle assessment in French) or ESQCV (Grisel and Duranthon, 2001; Ventere, 2000) is a semiquantitative, matrix-based method. ESQCV highlights the weak points of the product, where LCA data would be useful to inform decision-makers. An example of application is the EcoCamps project to design sustainable holiday camps (LIFE Programme, 2004).

The rationale behind this choice of tools is to cover a wide range of ecodesign tools, from LCA to guidelines. These tools were not mentioned in the interviews, except for LCA. We can therefore assume that they have at best a low visibility in the French construction sector. The objective here is to test whether, if those tools were widely known, there would still be gaps in the toolset available to designers.

Scales for completing the matrices were 0. No/Never; 1 . Very few; 2. A few/rarely; 3. Some/sometimes; and 4. Many/Often. The data was obtained as follows: 
- For Matrix A (situations * problems), expert data was obtained from two environmental consultants. Each interviewee filled in a matrix, after which mean values were calculated. As mentioned in Section 4.2., environmental consultants are central to the interplay between technical characteristics and their environmental significance. This is why we asked them specifically, rather than the people we had interviewed previously.

- The interviews showed that professional building designers have limited or no knowledge of tools other than LCA and certification frameworks. Therefore matrix B (tools * problems) and matrix C (situations * tools) were completed based on the analysis of the literature on the tools under evaluation. Values were discussed between the authors until a consensus was reached. The tools have different levels of depth or specificity. For matrix $B$, the rationale was to evaluate whether a tool was able to provide any help given a certain problem (matrix B), for instance, if environmental data is really hard to come by, complete LCA will fall short. For matrix $\mathrm{C}$ we looked at whether a tool is helpful at one stage. For instance, when choosing the HVAC system, EcoDesign Pilot is too generic for a very specific and complex system. When choosing programme requirements, LCA is powerless because data is almost nonexistent, therefore only broad projections can be made.

- Weighting coefficients for matrix D come from expert opinion. The authors asked three experts to rank problems and usage situations. Problems were ranked with regard to their importance and difficulty to solve. Usage situations were ranked with regard to the perceived impact of decisions made at this stage on the final environmental impact of the building. The experts were one academic carrying research on building design, a construction project management consultant with over twenty years of practice and teaching, and an architectengineer with more than ten years in architecture, technical supervision and environmental coordination, the two latter had been interviewed previously. These experts were preferred over the people interviewed previously because they had some knowledge of the design engineering perspective we take on the construction sector. The Borda count (Borda, 1781) was used to reach a single value for each item. According to Hazelrigg, the Borda count "is acclaimed to be the scoring method least likely to produce anomalous result" (Hazelrigg, 2003). In the Borda count, "given the rankings of all individuals . . the Borda count of an alternative is the total number of alternatives ranked below it. The alternatives are then ranked in decreasing order of their Borda counts." (Goddard, 1983) More explicitly, in a Borda count on $\mathrm{N}$ items, in each vote the prime choice gets $\mathrm{N}$ points, the second $\mathrm{N}-1$, and so on. Then points are summed for all voters. Equation 1 shows the calculation for the weights 
Accepted manuscript for: Lamé, Leroy, and Yannou. 2017. "Ecodesign Tools in the Construction Sector: Analyzing Usage Inadequacies with Designers' Needs." Journal of Cleaner Production. doi:10.1016/j.jclepro.2017.01.173.

on the importance of problems, in the case of $\mathrm{N}$ problems being ranked by $\mathrm{M}$ voters. In our case $\mathrm{M}=3$ and $\mathrm{N}=5$ for usage situations and 7 for problems.

$$
\operatorname{importance}(p)=\sum_{k=1}^{M}\left(N * M-\operatorname{rank}_{p}(k)+N\right)(\text { eq. 1) }
$$

The computation from initial matrices $A, B$ and $C$ to matrix $D$, and then to the final value in matrix $E$, is presented in equations 2 and 3 :

$$
\begin{gathered}
D_{i j}=\operatorname{Max}\left[0 ; \frac{A_{i j}}{\operatorname{Max}_{k l}\left(A_{k l}\right)}-\frac{C B_{i j}}{\operatorname{Max}_{k l}\left(C B_{k l}\right)}\right](\text { eq. } 2) \\
E_{i j}=\operatorname{size}(i) * \text { importance }(j) * D_{i j} \text { (eq. 3) }
\end{gathered}
$$

The data flow is shown in figure 5. Results of the DSM Value Bucket analysis are shown in table 1. 


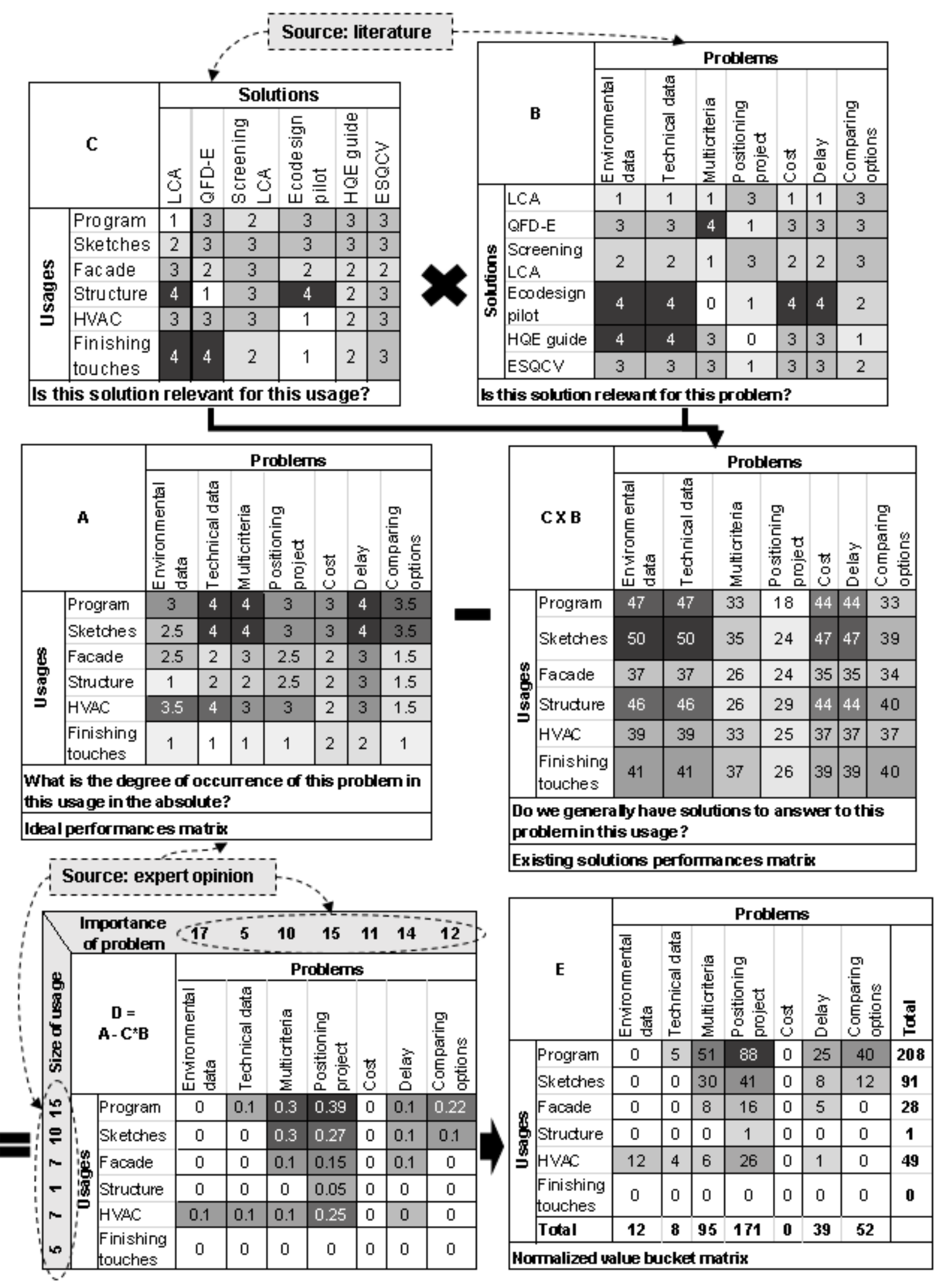

Figure 5 - DSM VB data flow 


\begin{tabular}{|c|c|c|c|c|c|c|c|c|c|}
\hline & \multirow[b]{2}{*}{$\mathbf{E}$} & \multicolumn{8}{|c|}{ Problems } \\
\hline & & 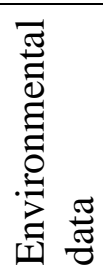 & 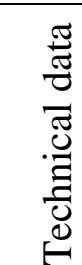 & 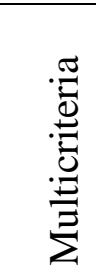 & 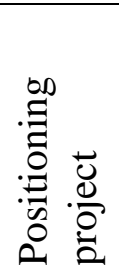 & $\begin{array}{l}\vec{y} \\
\dot{0}\end{array}$ & $\frac{\vec{\pi}}{0}$ & 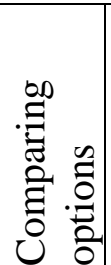 & $\stackrel{\bar{\sigma}}{\theta}$ \\
\hline \multirow{7}{*}{ 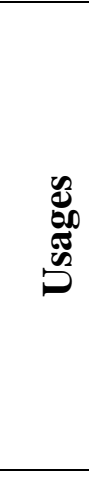 } & \multirow{6}{*}{$\begin{array}{l}\text { Program } \\
\text { Sketches } \\
\text { Facade } \\
\text { Structure } \\
\text { HVAC } \\
\text { Finishing } \\
\text { touches }\end{array}$} & 0 & 5 & 51 & 88 & 0 & 25 & 40 & 208 \\
\hline & & 0 & 0 & 30 & 41 & 0 & 8 & 12 & 91 \\
\hline & & 0 & 0 & 8 & 16 & 0 & 5 & 0 & 28 \\
\hline & & 0 & 0 & 0 & 1 & 0 & 0 & 0 & 1 \\
\hline & & 12 & 4 & 6 & 26 & 0 & 1 & 0 & 49 \\
\hline & & 0 & 0 & 0 & 0 & 0 & 0 & 0 & $\mathbf{0}$ \\
\hline & Total & 12 & 8 & 95 & 171 & 0 & 39 & 52 & \\
\hline \multicolumn{10}{|c|}{ Normalized value bucket matrix } \\
\hline
\end{tabular}

Table 1 - Results of DSM Value Bucket Tool (matrix E), rounded to the nearest integer value

In Table 1, the five top values are detached from the others (all 5 are over 30, whilst the next biggest value is 26 ). In matrix $E$, where the value is zero, tools already exist that could alleviate designers' issues (the difference between the desired ideal performance and the performance offered by existing solutions is small). In other boxes, values should be read comparatively. The higher the value (darker boxes), the wider the gap between the desired ideal performance and the performance offered by existing solutions. Development efforts should focus on the widest gaps, i.e., by decreasing order of importance:

1. $E_{1,4}$ : Project positioning environmental performance when writing requirements, i.e. evaluating the harshness of the requirements and how stringent they are regarding environmental performance.

2. $E_{1,3}$ : Developing multicriteria assessment for program, i.e. tools to assess how the specification of a certain requirement can impact all the dimensions of project performance (e.g. how specifying environmental certifications can impact cost).

3. $E_{2,4}$ : Project positioning at the sketches stage.

4. $E_{1,5}$ : Comparing options at the program stage, i.e. assessing the impact of different choices made at this early stage.

5. $E_{2,3}$ : Developing multicriteria assessment for sketches, i.e. tools to assess how functionality, cost, delays and environmental impacts as well as other criteria balance each other in early phases. 
In a more general way, "project positioning" and "multi criteria" are the two columns with the highest sum of values, and for the lines the item with the highest sum of values is program, then sketches, and then HVAC.

\section{Discussion}

\subsection{Lack of environmental and technical data}

Lack of data is usually considered a key issue for building ecodesign, e.g. (Khasreen et al., 2009; Reap et al., 2008b) in the case of LCA. Here, this barrier is rated very low after computation with the DSM VB tool. There are two reasons for this: many tools exist which do not require extensive quantitative data (in our analysis, the HQE guide, EcoDesign Pilot, and QFD-E and ESQCV), and looking at matrix A in Figure 5 experts consider this problem to be less pressing than issues such as delay in analysis or multicriteria evaluation. New studies on the impact of taking generic data in LCA (Silvestre et al., 2015) should help to address this issue.

"Lack of technical data" also scores very low. This issue is rated high by experts for the program and sketches stages, but here again, tools exist for stages where there is still a high uncertainty on the specific technical choices. They remain largely unknown by practitioners but, combined together, they could help solve issues related to the lack of technical data.

\subsection{Interpreting evaluation results}

Problems appear to be more closely linked to the interpretation of results than to analysis itself. This aspect has already been underlined in theory (Reap et al., 2008b) and our study confirms empirically that practitioners encounter this issue. In the professional community, the need to develop methods to understand and give meaning to LCA data has been highlighted in a study of 10 French construction projects (ADEME et al., 2015).

The need to move towards multicriteria evaluation and sustainability concepts has been identified regularly (Cole, 2005; Ding, 2008; Haapio and Viitaniemi, 2008). A recent international conference on LCA and Construction concluded to the need to "improve the interpretation of results by developing benchmarks to compare buildings from localized average types or best practice" and "develop decision-making tools and methods for construction stakeholders" (Lasvaux et al., 2014). These elements are quite similar to "comparing options", "multicriteria" and "project positioning". Nonetheless, the present conclusions are more precise as they specify precise steps in the process when these methodologies need to be provided to designers. First elements of solution exist, e.g. the definition of typologies or reference models for building energy consumption (Ballarini et al., 2014; 
EPISCOPE, 2016). However more global benchmark scenarios are still to be developed to allow the comparison of LCA results.

\subsection{The DSM VB for building ecodesign: where, when and how}

The methodology presented in Section 3.1. combines multiple data collection methods to feed the DSM VB tool. In this project, data collection alone would not have yielded the same results: interviewees often argued that lack of data was a significant issue for them, one they could not solve easily. However, it is shown that today this is not the main issue. During a feedback meeting on this project, participants agreed that the results were in line with their experience. One major advantage of the DSM VB analysis is therefore that it reveals hidden issues that are not directly mentioned by practitioners: its structuralist perspective is complementary to survey-based research. It also forces the careful definition of a set of problems, usage situations and the extraction of a set of archetypal existing solutions, which produces a usage-centered model of the situation. In the analysis of implementation in a given perimeter (in the present case, the French construction industry), this approach can provide ecodesign researchers and developers with insights on where to focus their efforts concerning both development and transfer to industry.

\section{Conclusion}

\subsection{Contributions}

In this article a method for analyzing ecodesign practice is applied in the French construction sector. A methodology is presented which combines a large empirical study and a tool from innovation management for data analysis. The first contribution is the empirical gathering of expectations and needs of building designers concerning ecodesign tools, which leads to the identification of gaps in the coverage of designers' needs by existing ecodesign tools. The lack of multicriteria methods for the integration of environmental analysis into decision making and the lack of benchmarks to which designers can compare their projects are identified as major barriers. This is new information for ecodesign tool developers, which complements more theoretical studies, e.g. (Reap et al., 2008a).

The article also makes a methodological contribution by extending the range of application of the DSM VB tool to ecodesign tools. DSM VB has been used in many different sectors, and continues to prove its usefulness. It promotes the definition of usage-problem-solutions model of a problem situation, which allows to identify causes of perceived problems.

\subsection{Perspectives}

Besides the results on needed ecodesign tools for multicriteria analysis and benchmarking in early design stages, our study indicates wider perspectives for building ecodesign. Tools are only one 
Accepted manuscript for: Lamé, Leroy, and Yannou. 2017. "Ecodesign Tools in the Construction Sector: Analyzing Usage Inadequacies with Designers' Needs." Journal of Cleaner Production. doi:10.1016/j.jclepro.2017.01.173.

aspect of the solution: it is not only a case of providing the perfect tool, but also of creating a context where tools can be implemented.

\section{Building design process}

The current process of building design prevents integrated design. However, integrated design is an important enabler for designing green buildings (Rekola et al., 2012) in a context of increasingly complex systems (Srebric, 2008). The rigid sequence of contractual arrangements may prevent different options to be investigated in parallel, and then regardless of tools designers cannot compare what they have not designed. Moreover, the absence of an environmental specialist from the beginning to the end of the project poses the problem of coordination of the environmental dimension of the project. We have underlined (Section 4.2) the importance of a key actor: the environmental consultancy. Environmental consultancies work for and on behalf of the client. As they usually perform environmental analysis and manage certification processes, they have to interact with and centralize data from all designers (architects and engineers of all specialties: HVAC, structure, etc.).

At present, environmental consultancies are rarely present at the beginning of projects. Their role is often limited to certification, and sometimes LCA. Nonetheless environmental consultancies try to be more and more present for earlier design phases, as early as the program phase. It is in their interest but also in their clients' interest to do so: the earlier the environmental dimension is integrated, the larger the potential for improved environmental performance. Moreover, as construction is a project-led industry, teams and consortia are recomposed regularly. Environmental consultancies are the most likely to store knowledge from various experiences, as they have the widest access to information from different actors. During interviews, environmental consultancies were the most proactive on environmental knowledge management inside projects, and between projects using feedback information. They could at the same time be environmental experts in the design team, and provide tools to other actors.

\section{Technological perspectives}

In the future, computer tools for data sharing and system modelling should be helpful. Interviewees have high hopes that BIM will be of great help to their practice. Future information technology will enhance model sharing and connection (Wong and Zhou, 2015). This will encourage, for instance, the connection of design with energy modelling (Geyer, 2012). The present research shows that environmental consultancies should play a key role in the management of these systems. This is in their interest, as BIM will enable quicker certification and LCA (Wong and Zhou, 2015). BIM could also bring continuity in a fragmented process and provide contractors, and even maintenance, with fuller information from designers. However, besides diffusion and training issues, a challenge remains to 
be solved on the sharing of proprietary information through these systems and the ownership and responsibility of each actor on the system. Again, the issues of process integration and management are crucial, and propositions for engineering platforms focused on ecodesign, e.g. (Dufrene et al., 2013), could help.

\section{Research-practice gap and regulation}

The transfer from research into practice is a major issue, and the situation does not appear to have changed significantly since the analysis of Baumann et al. (2002). Most tools developed do not reach professional practice. This indicates that there is still a lack of testing and an abundant number of tools whereas insufficient attention is paid to their improvement and implementation. The results of this study show that the main issue for practitioners is on making decisions rather than on acquiring ever more sophisticated tools to evaluate what they did. However, if tools require any expertise or training, i.e. if their implementation comes at a cost, we have seen that companies in the building sector tend to limit their effort to the legislative minimum or to what's included in labels and certifications. Standards and regulations are a major enabler for building ecodesign and can force professionals to investigate efficient methods developed by researchers since it will give them a competitive advantage.

\section{Acknowledgements}

The authors wish to express their grateful thanks to the Chair Bouygues Construction "Sustainable Buildings and Innovation" for scientific and financial support, and the interviewees who participated in this study. We also thank two of the anonymous reviewers for their insightful comments.

\section{References}

ADEME, 2013. Les chiffres clés du bâtiment [WWW Document]. URL multimedia.ademe.fr/catalogues/chiffres-cles-batiment-2013/ (accessed 6.13.16).

ADEME, Ekopolis, IFPEB, 2015. Etude - Témoignages et propositions de la communauté francilienne d'expérimentation : janvier 2013 - juillet 2014. Paris, France.

AFNOR, ADEME, 2008. Panorama des initiatives françaises dans le domaine de l'éco-conception. AFNOR, Saint-Denis, France.

Anderson, J.E., Wulfhorst, G., Lang, W., 2015. Energy analysis of the built environment-A review and outlook. Renew. Sustain. Energy Rev. 44, 149-158. doi:10.1016/j.rser.2014.12.027

Attia, S., Gratia, E., De Herde, A., Hensen, J.L.M., 2012. Simulation-based decision support tool for early stages of zero-energy building design. Energy Build. 49, 2-15. doi:10.1016/j.enbuild.2012.01.028

Attia, S., Hensen, J.L.M., Beltrán, L., De Herde, A., 2011. Selection criteria for building performance simulation tools: contrasting architects' and engineers' needs. J. Build. Perform. Simul. 5, 155-169. doi:10.1080/19401493.2010.549573 

Inadequacies with Designers' Needs." Journal of Cleaner Production. doi:10.1016/j.jclepro.2017.01.173.

Ballarini, I., Corgnati, S.P., Corrado, V., 2014. Use of reference buildings to assess the energy saving potentials of the residential building stock: The experience of TABULA project. Energy Policy 68, 273-284. doi:10.1016/j.enpol.2014.01.027

Baumann, H., Boons, F., Bragd, A., 2002. Mapping the green product development field: engineering, policy and business perspectives. J. Clean. Prod. 10, 409-425. doi:10.1016/S09596526(02)00015-X

Bey, N., Hauschild, M.Z., McAloone, T.C., 2013. Drivers and barriers for implementation of environmental strategies in manufacturing companies. CIRP Ann. - Manuf. Technol. 62, 4346. doi:10.1016/j.cirp.2013.03.001

Birch, A., Hon, K.K.B., Short, T., 2012. Structure and output mechanisms in Design for Environment (DfE) tools. J. Clean. Prod. 35, 50-58. doi:10.1016/j.jclepro.2012.05.029

Blessing, L.T.M., Chakrabarti, A., 2009. DRM, a design research methodology. Springer, Dordrecht ; London.

Borda, M. de, 1781. Mémoire sur les Élections au Scrutin. Académie Royale des Sciences, Paris, France.

Bovea, M.D., Pérez-Belis, V., 2012. A taxonomy of ecodesign tools for integrating environmental requirements into the product design process. J. Clean. Prod. 20, 61-71. doi:10.1016/j.jclepro.2011.07.012

Browning, T.R., 2001. Applying the design structure matrix to system decomposition and integration problems: a review and new directions. Eng. Manag. IEEE Trans. On 48, 292-306.

Bryde, D., Broquetas, M., Volm, J.M., 2013. The project benefits of Building Information Modelling (BIM). Int. J. Proj. Manag. 31, 971-980. doi:10.1016/j.ijproman.2012.12.001

Buckingham, M., Antelmi Pigosso, D.C., Dekoninck, E.A., McAloone, T.C., 2014. Supporting eco-design implementation within small and large companies, in: DS 77: Proceedings of the DESIGN 2014 13th International Design Conference. Presented at the DESIGN 2014, Design Society, Dubrovnik, Croatia, pp. 1473-1482.

BVA, ADEME, 2010. Première étude sur le déploiement de l'éco-conception en France et sur les attentes et besoins des entreprises. ADEME.

Cabeza, L.F., Rincón, L., Vilariño, V., Pérez, G., Castell, A., 2014. Life cycle assessment (LCA) and life cycle energy analysis (LCEA) of buildings and the building sector: A review. Renew. Sustain. Energy Rev. 29, 394-416. doi:10.1016/j.rser.2013.08.037

Chick, A., Micklethwaite, P., 2004. Specifying recycled: understanding UK architects' and designers' practices and experience. Des. Stud. 25, 251-273. doi:10.1016/j.destud.2003.10.009

Cole, R.J., 2005. Building environmental assessment methods: redefining intentions and roles. Build. Res. Inf. 33, 455-467. doi:10.1080/09613210500219063

Cooper, J.S., Fava, J.A., 2008. Life-Cycle Assessment Practitioner Survey: Summary of Results. J. Ind. Ecol. 10, 12-14. doi:10.1162/jiec.2006.10.4.12

Deutz, P., McGuire, M., Neighbour, G., 2013. Eco-design practice in the context of a structured design process: an interdisciplinary empirical study of UK manufacturers. J. Clean. Prod. 39, 117128. doi:10.1016/j.jclepro.2012.08.035

Ding, G.K., 2008. Sustainable construction-The role of environmental assessment tools. J. Environ. Manage. 86, 451-464.

Dufrene, M., Zwolinski, P., Brissaud, D., 2013. An engineering platform to support a practical integrated eco-design methodology. CIRP Ann. - Manuf. Technol. 62, 131-134. doi:10.1016/j.cirp.2013.03.065

EPISCOPE, 2016. Monitor progress towards climate targets in European housing stocks main results of the EPISCOPE Projekt: final project report: (deliverable D1.2). Institut Wohnen und Umwelt $\mathrm{GmbH}$, Darmstadt.

Geyer, P., 2012. Systems modelling for sustainable building design. Adv. Eng. Inform. 26, 656-668. doi:10.1016/j.aei.2012.04.005

Gillis, W., Cudney, E., 2014. A New Methodology for Eco-friendly Construction: Utilizing Quality Function Deployment to Meet LEED Requirements, in: Azevedo, S.G., Brandenburg, M., 
Carvalho, H., Cruz-Machado, V. (Eds.), Eco-Innovation and the Development of Business Models, Greening of Industry Networks Studies. Springer International Publishing, pp. 245273.

Gobin, C., 2011. Éco-conception Marqueur d'un reengineering de la construction. Tech. Ing. L'ingénierie de la cosntruction.

Goddard, S.T., 1983. Ranking in Tournaments and Group Decisionmaking. Manag. Sci. 29, 1384-1392. Goodall, P., Rosamond, E., Harding, J., 2014. A review of the state of the art in tools and techniques used to evaluate remanufacturing feasibility. J. Clean. Prod. 81, 1-15. doi:10.1016/j.jclepro.2014.06.014

Grisel, L., Duranthon, G., 2001. Pratiquer l'éco-conception: lignes directrices, AFNOR pratique. AFNOR, Paris-La Défense.

Haapio, A., Viitaniemi, P., 2008. A critical review of building environmental assessment tools. Environ. Impact Assess. Rev. 28, 469-482.

Häkkinen, T., Belloni, K., 2011. Barriers and drivers for sustainable building. Build. Res. Inf. 39, 239255. doi:10.1080/09613218.2011.561948

Hazelrigg, G.A., 2003. Validation of engineering design alternative selection methods. Eng. Optim. 35, 103-120. doi:10.1080/0305215031000097059

Hazelrigg, G.A., 1998. A Framework for Decision-Based Engineering Design. J. Mech. Des. 120, 653. doi:10.1115/1.2829328

IEA Annex 31, 2004. Directory of tools - A Survey of LCA Tools, Assessment Frameworks, Rating Systems, Technical Guidelines, Catalogues, Checklists and Certificates. International Energy Agency - Annex 31 : Energy-Related Environmental Impact of Buildings.

ISO, 2006. ISO 14044:2006 - Environmental management -- Life cycle assessment -- Requirements and guidelines. International Organization for Standardization, Geneva, Switzerland.

ISO, 2002. ISO/TR 14062:2002 - Environmental management - Integrating environmental aspects into product design and development. International Organization for Standardization, Geneva, Switzerland.

Janin, M., Bellini, B., 2011. Écoconception: état de l'art des outils disponibles. Tech. Ing. Ind. Procédés Défis Nouv. Approch. base documentaire : TIB442DUO.

Jeswiet, J., Hauschild, M., 2005. EcoDesign and future environmental impacts. Mater. Des. 26, 629634. doi:10.1016/j.matdes.2004.08.016

Khasreen, M.M., Banfill, P.F.G., Menzies, G.F., 2009. Life-Cycle Assessment and the Environmental Impact of Buildings: A Review. Sustainability 1, 674-701. doi:10.3390/su1030674

Lasvaux, S., Ventura, A., Habert, G., De La Roche, C., Hermel, K., Feraille, A., Tardivel, Y., Tessier, C., 2014. Linking research activities and their implementation in practice in the construction sector: the LCA Construction 2012 experience. Int. J. Life Cycle Assess. 19, 463-470. doi:10.1007/s11367-013-0682-1

Le Pochat, S., Bertoluci, G., Froelich, D., 2007. Integrating ecodesign by conducting changes in SMEs. J. Clean. Prod. 15, 671-680. doi:10.1016/j.jclepro.2006.01.004

Leroy, Y., Cluzel, F., Zaraket, T., Lasvaux, S., Bentos, M., 2013. Integrating LCA-based models into design process for buildings: a study of the existing practices in France, in: Proceedings of the 6th International Conference on Life Cycle Management. Presented at the LCM2013, Gothenburg, Sweden, pp. 738-741.

LIFE Programme, 2004. ECO-CAMPS - Eco-design and eco-engineering of buildings, amenities and accommodations in campsites. Project ref LIFE04 ENV/FR/000321. [WWW Document]. URL http://ec.europa.eu/environment/life/project/Projects/index.cfm?fuseaction=search.dspPag e\&n_proj_id=2719\#PD (accessed 12.11.15).

Lindahl, M., 2006. Engineering designers' experience of design for environment methods and tools Requirement definitions from an interview study. J. Clean. Prod. 14, 487-496. doi:10.1016/j.jclepro.2005.02.003

Lofthouse, V., 2006. Ecodesign tools for designers: defining the requirements. J. Clean. Prod. 14, 1386-1395. doi:10.1016/j.jclepro.2005.11.013 

Inadequacies with Designers' Needs." Journal of Cleaner Production. doi:10.1016/j.jclepro.2017.01.173.

Malmqvist, T., Glaumann, M., Scarpellini, S., Zabalza, I., Aranda, A., Llera, E., Díaz, S., 2011. Life cycle assessment in buildings: The ENSLIC simplified method and guidelines. Energy 36, 19001907. doi:10.1016/j.energy.2010.03.026

Masui, K., Sakao, T., Kobayashi, M., Inaba, A., 2003. Applying Quality Function Deployment to environmentally conscious design. Int. J. Qual. Reliab. Manag. 20, 90-106.

Menet, J.-L., Gruescu, C., 2014. L'éco-conception dans le bâtiment en 37 fiches-outils. Dunod, Paris.

Millet, D., Bistagnino, L., Lanzavecchia, C., Camous, R., Poldma, T., 2007. Does the potential of the use of LCA match the design team needs? J. Clean. Prod. 15, 335-346.

Moberg, Å., Johansson, M., Finnveden, G., Jonsson, A., 2010. Printed and tablet e-paper newspaper from an environmental perspective - A screening life cycle assessment. Environ. Impact Assess. Rev. 30, 177-191. doi:10.1016/j.eiar.2009.07.001

Nibel, S., Valicourt, D. de, 2012. Programmer, concevoir, réaliser et exploiter un bâtiment durable : mettre en oeuvre un système de management d'opération: mode d'emploi. CSTB éd., Marne-la-Vallée.

Olinzock, M., Landis, A., Saunders, C., Collinge, W., Jones, A., Schaefer, L., Bilec, M., 2015. Life cycle assessment use in the North American building community: summary of findings from a 2011/2012 survey. Int. J. Life Cycle Assess. 20, 318-331. doi:10.1007/s11367-014-0834-y

Ortiz, O., Castells, F., Sonnemann, G., 2009. Sustainability in the construction industry: A review of recent developments based on $\{$ LCA $\}$. Constr. Build. Mater. 23, 28-39. doi:https://dx-doiorg.bibliopam.ecp.fr/10.1016/j.conbuildmat.2007.11.012

Osmani, M., Glass, J., Price, A.D.F., 2008. Architects' perspectives on construction waste reduction by design. Waste Manag. 28, 1147-1158. doi:10.1016/j.wasman.2007.05.011

Pahl, G., Beitz, W., 1996. Engineering design: a systematic approach. Springer, London ; New York, NY.

Passer, A., Lasvaux, S., Allacker, K., De Lathauwer, D., Spirinckx, C., Wittstock, B., Kellenberger, D., Gschösser, F., Wall, J., Wallbaum, H., 2015. Environmental product declarations entering the building sector: critical reflections based on 5 to 10 years experience in different European countries. Int. J. Life Cycle Assess. 20, 1199-1212. doi:10.1007/s11367-015-0926-3

Persson, J., Grönkvist, S., 2014. Drivers for and barriers to low-energy buildings in Sweden. J. Clean. Prod. doi:10.1016/j.jclepro.2014.09.094

Peuportier, B., Thiers, S., Guiavarch, A., 2013. Eco-design of buildings using thermal simulation and life cycle assessment. J. Clean. Prod. 39, 73-78. doi:10.1016/j.jclepro.2012.08.041

Poulikidou, S., Björklund, A., Tyskeng, S., 2014. Empirical study on integration of environmental aspects into product development: processes, requirements and the use of tools in vehicle manufacturing companies in Sweden. J. Clean. Prod. 81, 34-45. doi:10.1016/j.jclepro.2014.06.001

Reap, J., Roman, F., Duncan, S., Bras, B., 2008a. A survey of unresolved problems in life cycle assessment - Part 1: goal and scope and inventory analysis. Int. J. Life Cycle Assess. 13, 290300. doi:10.1007/s11367-008-0008-x

Reap, J., Roman, F., Duncan, S., Bras, B., 2008b. A survey of unresolved problems in life cycle assessment - Part 2: impact assessment and interpretation. Int. J. Life Cycle Assess. 13, 374388. doi:10.1007/s11367-008-0009-9

Reijnders, L., van Roekel, A., 1999. Comprehensiveness and adequacy of tools for the environmental improvement of buildings. J. Clean. Prod. 7, 221-225. doi:10.1016/S0959-6526(99)00080-3

Rekola, M., Mäkeläinen, T., Häkkinen, T., 2012. The role of design management in the sustainable building process. Archit. Eng. Des. Manag. 8, 78-89. doi:10.1080/17452007.2012.659503

Reyes, T., 2007. L'éco-conception dans les PME : les mécanismes du cheval de Troie méthodologique et du choix de trajectoires comme vecteurs d'intégration de l'environnement en conception (PhD thesis). Université du Sud Toulon-Var, Toulon, France.

Rincón, L., Castell, A., Pérez, G., Solé, C., Boer, D., Cabeza, L.F., 2013. Evaluation of the environmental impact of experimental buildings with different constructive systems using Material Flow 
Accepted manuscript for: Lamé, Leroy, and Yannou. 2017. "Ecodesign Tools in the Construction Sector: Analyzing Usage Inadequacies with Designers' Needs." Journal of Cleaner Production. doi:10.1016/j.jclepro.2017.01.173.

Analysis and Life Cycle Assessment. Appl. Energy 109, 544-552. doi:10.1016/j.apenergy.2013.02.038

Rogers, E.M., 2003. Diffusion of innovations, 5th ed. ed. Free Press, New York, NY.

Saunders, C.L., Landis, A.E., Mecca, L.P., Jones, A.K., Schaefer, L.A., Bilec, M.M., 2013. Analyzing the Practice of Life Cycle Assessment. J. Ind. Ecol. 17, 777-788. doi:10.1111/jiec.12028

Scheuer, C., Keoleian, G.A., Reppe, P., 2003. Life cycle energy and environmental performance of a new university building: modeling challenges and design implications. Energy Build. 35, 1049-1064. doi:10.1016/S0378-7788(03)00066-5

Short, T., Lee-Mortimer, A., Luttropp, C., Johansson, G., 2012. Manufacturing, sustainability, ecodesign and risk: lessons learned from a study of Swedish and English companies. J. Clean. Prod. 37, 342-352. doi:10.1016/j.jclepro.2012.07.037

Silvestre, J.D., Lasvaux, S., Hodková, J., de Brito, J., Pinheiro, M.D., 2015. NativeLCA - a systematic approach for the selection of environmental datasets as generic data: application to construction products in a national context. Int. J. Life Cycle Assess. 20, 731-750. doi:10.1007/s11367-015-0885-8

Srebric, J., 2008. Editorial: Sustainable Building Systems Require New Design Guidelines. HVACR Res. 14, 1-1. doi:10.1080/10789669.2008.10390990

Succar, B., 2009. Building information modelling framework: A research and delivery foundation for industry stakeholders. Autom. Constr. 18, 357-375.

Suzer, O., 2015. A comparative review of environmental concern prioritization: LEED vs other major certification systems. J. Environ. Manage. 154, 266-283. doi:10.1016/j.jenvman.2015.02.029

Takano, A., Winter, S., Hughes, M., Linkosalmi, L., 2014. Comparison of life cycle assessment databases: A case study on building assessment. Build. Environ. 79, 20-30. doi:10.1016/j.buildenv.2014.04.025

The EeBGuide Project, 2012. EeBGuide Guidance Document - Part B: BUILDINGS. The Energy-Efficient Building European Initiative.

Vallet, F., Eynard, B., Millet, D., Mahut, S.G., Tyl, B., Bertoluci, G., 2013. Using eco-design tools: An overview of experts' practices. Des. Stud. 34, 345-377. doi:10.1016/j.destud.2012.10.001

van Hemel, C., Cramer, J., 2002. Barriers and stimuli for ecodesign in SMEs. Integrating Greener Prod. Dev. Perspect. 10, 439-453. doi:10.1016/S0959-6526(02)00013-6

Ventere, J.-P., 2000. L'éco-conception : une démarche préventive - On ne fait pas d'éco-conception sans le savoir : le discours sur la méthode. Ann. Mines - Responsab. Environ. 31-36.

Vienna TU, Institute for Engineering Design, 2012. Ecodesign Pilot online [WWW Document]. URL http://www.ecodesign.at/pilot/ (accessed 10.28.14).

Walden, D.D., Roedler, G.J., Forsberg, K., Hamelin, R.D., Shortell, T.M., International Council on Systems Engineering (Eds.), 2015. Systems engineering handbook: a guide for system life cycle processes and activities, 4th edition. ed. John Wiley \& Sons Inc, Hoboken, NJ.

Wang, W., Zmeureanu, R., Rivard, H., 2005. Applying multi-objective genetic algorithms in green building design optimization. Build. Environ. 40, 1512-1525. doi:10.1016/j.buildenv.2004.11.017

Wever, R., van Kuijk, J., Boks, C., 2008. User-centred design for sustainable behaviour. Int. J. Sustain. Eng. 1, 9-20. doi:10.1080/19397030802166205

Wimmer, W., Züst, R., 2001. ECODESIGN Pilot: product-investigation-, learning- and optimization-tool for sustainable product development, with CD-ROM, Alliance for global sustainability bookseries. Kluwer Academic Publishers, Dordrecht ; Boston.

Wong, J.K.W., Zhou, J., 2015. Enhancing environmental sustainability over building life cycles through green BIM: A review. Autom. Constr. 57, 156-165. doi:10.1016/j.autcon.2015.06.003

Wood, L.C., Wang, C., Abdul-Rahman, H., Jamal Abdul-Nasir, N.S., 2016. Green hospital design: integrating quality function deployment and end-user demands. J. Clean. Prod. 112, 903913. doi:10.1016/j.jclepro.2015.08.101 
Yannou, B., 2015. Supporting need seeker innovation: the Radical Innovation Design methodology, in: DS 80-8 Proceedings of the 20th International Conference on Engineering Design. Presented at the ICED'15, The Design Society, Milano, Italy, pp. 51-60.

Yannou, B., Cluzel, F., Farel, R., 2016. Capturing the relevant problems leading to pain- and usagedriven innovations: The Dependency Structure Modeling Value Bucket algorithm. Concurr. Eng. doi:10.1177/1063293X16666311

Yannou, B., Jankovic, M., Leroy, Y., Okudan Kremer, G.E.O., 2013. Observations From Radical Innovation Projects Considering the Company Context. J. Mech. Des. 135, 021005 (17p). doi:10.1115/1.4023150

Zhang, F., Rio, M., Allais, R., Zwolinski, P., Reyes, T., Roucoules, L., Mercier-Laurent, E., Buclet, N., 2013. Toward an systemic navigation framework to integrate sustainable development into the company. J. Clean. Prod. 54, 199-214. doi:10.1016/j.jclepro.2013.03.054

Zuo, J., Zhao, Z.-Y., 2014. Green building research-current status and future agenda: A review. Renew. Sustain. Energy Rev. 30, 271-281. doi:10.1016/j.rser.2013.10.021 


\section{Supplementary file 1 Profiles of the interviewees}

Table S.1 - Profiles of interviewees of phase 1 (F: face to face, P: phone)

\begin{tabular}{|c|c|c|c|c|c|}
\hline 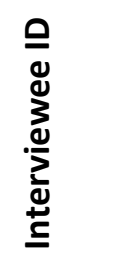 & 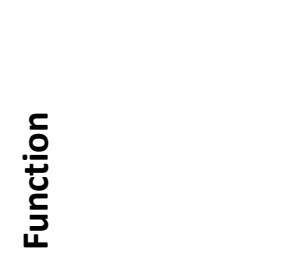 & 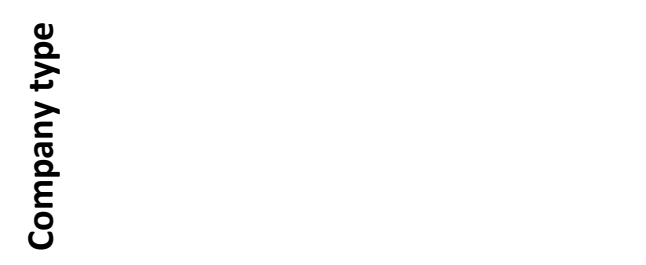 & 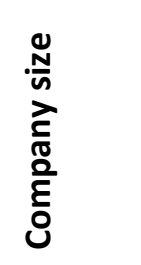 & 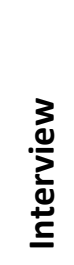 & 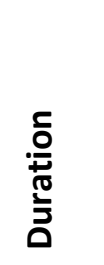 \\
\hline 1 & Director & $\begin{array}{l}\text { Project management assistance } \\
\text { consultancy }\end{array}$ & $<3 p$ & $\mathrm{~F}$ & $1 \mathrm{~h} 30^{\prime}$ \\
\hline 2 & $\begin{array}{l}\text { Researcher and } \\
\text { teacher }\end{array}$ & $\begin{array}{l}\text { Research in architecture and urban } \\
\text { planning }\end{array}$ & & $P$ & $1 \mathrm{~h}$ \\
\hline 3 & Project manager & Environmental engineering consultancy & $10-50 p$ & $\mathrm{P}$ & $1 \mathrm{~h}$ \\
\hline 4 to 9 & Project managers & Real estate development & $>500 p$ & $\mathrm{~F}$ & $1 \mathrm{~h} 30^{\prime}$ \\
\hline $10 \& 11$ & $\begin{array}{l}\text { Project manager, } \\
\text { design engineer }\end{array}$ & $\begin{array}{l}\text { Engineering consultancy (structural and } \\
\text { energy engineering) }\end{array}$ & $\begin{array}{l}>500 p \\
\text { (group) }\end{array}$ & $\mathrm{F}$ & $1 \mathrm{~h} 20^{\prime}$ \\
\hline
\end{tabular}




\begin{tabular}{|c|c|c|c|c|c|}
\hline 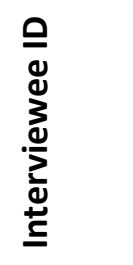 & 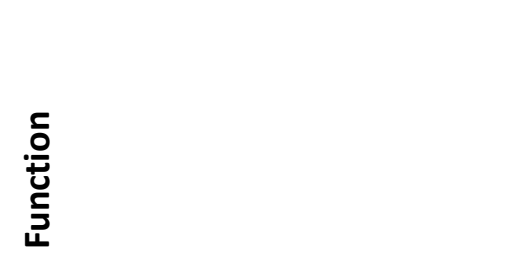 & 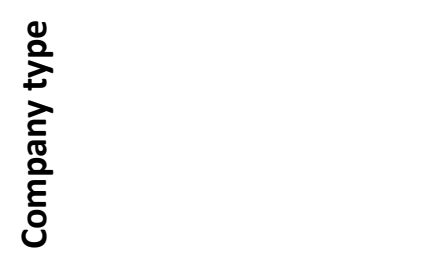 & $\begin{array}{l}\frac{N}{N} \\
\frac{N}{N} \\
\frac{c}{0} \\
\frac{0}{E} \\
0\end{array}$ & $\begin{array}{l}\stackrel{3}{2} \\
\frac{2}{2} \\
\underline{ \pm}\end{array}$ & 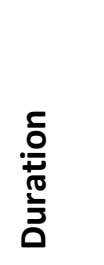 \\
\hline 1 & Urban planning consultant & $\begin{array}{l}\text { Environmental engineering } \\
\text { consultancy }\end{array}$ & $3-10 p$ & $\mathrm{~F}$ & $1 \mathrm{~h} 15^{\prime}$ \\
\hline 2 & Carbon impact consultant & Carbon impact consultancy & $<3 p$ & $\mathrm{P}$ & $1 \mathrm{~h}$ \\
\hline 3 & Project manager & $\begin{array}{l}\text { Urban planning } \\
\text { consultancy }\end{array}$ & $>500$ (group) & $\mathrm{F}$ & $1 \mathrm{~h} 15^{\prime}$ \\
\hline 4 & Director, project manager & $\begin{array}{l}\text { Environmental engineering } \\
\text { consultancy }\end{array}$ & 3-10p & $P$ & $30^{\prime}$ \\
\hline $5 \& 6$ & Project manager & $\begin{array}{l}\text { Real estate development } \\
\text { consultancy }\end{array}$ & 3-10 p & $\mathrm{F}$ & $1 \mathrm{~h} 15^{\prime}$ \\
\hline 7 & Director & $\begin{array}{l}\text { Project management } \\
\text { assistance consultancy }\end{array}$ & $<3 p$ & $\mathrm{~F}$ & $1 \mathrm{~h} 15^{\prime}$ \\
\hline 8 & Researcher and teacher & Research in architecture & & $\mathrm{F}$ & $1 \mathrm{~h}$ \\
\hline 9 & Researcher and teacher & Research in architecture & & $\mathrm{F}$ & $1 \mathrm{~h}$ \\
\hline $10 \& 11$ & Architects, directors & Architecture practice & $3-10 p$ & $\mathrm{~F}$ & $1 \mathrm{~h} 30$ \\
\hline 12 & $\begin{array}{l}\text { Project officer, advisor to } \\
\text { representatives }\end{array}$ & Local public authority & 5000 inhab. & $\mathrm{F}$ & $1 \mathrm{~h}$ \\
\hline $13 \& 14$ & Project manager, project officer & $\begin{array}{l}\text { Engineering consultancy } \\
\text { (structural and energy } \\
\text { engineering) }\end{array}$ & $10-50 p$ & $\mathrm{~F}$ & $45^{\prime}$ \\
\hline 15 & Project manager & $\begin{array}{l}\text { Environmental engineering } \\
\text { consultancy }\end{array}$ & $10-50 p$ & $\mathrm{~F}$ & $1 \mathrm{~h}$ \\
\hline 16 & Environmental project manager & Real estate development & $>500 p$ & $\mathrm{~F}$ & $1 \mathrm{~h} 15^{\prime}$ \\
\hline $17 \& 18$ & $\begin{array}{l}\text { Innovation project manager, } \\
\text { development project manager }\end{array}$ & Real estate development & $>500 p$ & $\mathrm{~F}$ & $1 \mathrm{~h} 15^{\prime}$ \\
\hline 19 & $\begin{array}{l}\text { Consultant in LCA of building } \\
\text { materials }\end{array}$ & Environmental consultancy & $10-50 p$ & $\mathrm{P}$ & $25^{\prime}$ \\
\hline
\end{tabular}




\section{Supplementary file 2 Questionnaires}

This is the script that was used for the interviews in phase 2 . The original French version is provided at the end of the document.

\section{Questionnaire for experts}

Date, place, name and surname of the interviewee.

Company, company type, size of the company.

Function of the interviewee, experience in the construction sector, initial training.

Experience in sustainable projects, specific training received.

Working particularly with a specific type of contract? (refers to the three French main contract categories in the construction sector)

\section{Presentation of the interviewer and his project}

Research intern at CSTB-ECP with a project on building ecodesign

Objective: understand how people work, the design process, its organization, based on the experience of experts

\section{Sustainability}

What's a sustainable project?

Any experience of such projects? Do you have an example?

\section{Sketches stage - architect selection}

Are you present during the architect's selection process?

What is your role during this stage?

What is at stake at this stage? What do you expect to obtain?

- Highlight values: social, environmental, economic, cultural/artistic

Who do you work/collaborate with?

- With whom are you contractually bound?

- How often do you meet other actors?

Do you feel to have power at this stage, can you influence decisions? On which points?

- List influence / decision potential

- Constraints: regulatory, company processes, economic, choice made by another actor

\section{Difference between " sustainable projects » and " regular ones »}

What changes at the sketches stage when a project is presented as "sustainable", "green"? How does this dimension appear?

Do you work differently? On which points? 
Accepted manuscript for: Lamé, Leroy, and Yannou. 2017. "Ecodesign Tools in the Construction Sector: Analyzing Usage Inadequacies with Designers' Needs." Journal of Cleaner Production. doi:10.1016/j.jclepro.2017.01.173.

- Decision-making

- Choice of actors

- Involvement of the building operator

- Involvement of users (inhabitants)

- In the use of information :

○ System-level (simulations, assessments, etc.)

- Sub-systems (partial simulations and assessments)

- Materials

- In tasks:
○ New tasks
- Modifications
- Deletions

What are the difficulties at the sketches stage in sustainable building design projects?

\section{Ecodesign tools}

Do you know any ecodesign tool ? Can you cite one ?

- Known tools

Do you use them ? Why ?

How could they be improved ? What would make them easier to use?

- Interfaces / effort / usage / usefulness

How do you account for the environmental dimension in your practice? How to reinforce this aspect? More precisely, do you use LCA?

- When?

- To what end?

- How could its use be made easier (support, training, regulations...)? Ideally, what should it allow you to do?

Do you use BIM?

- In what way?

- As a communication channel?

\section{End}

Do you have any final comment? 


\section{Questionnaire experts - Notes}

Date :

Lieu :

Nom, prénom :

Taille :
Compagnie :

Fonction :

Type d'entreprise :

Années d'expérience dans le secteur du bâtiment :

Etudes :

Expérience en projets durables : OUI / NON

Formation spécifique : OUI / NON

Travaillez-vous sur un type de contrat plus régulièrement que les autres :

Conception-réalisation / conception-réalisation-exploitation / concours d'esquisses + DCE

\section{PRESENTATION DE L'INTERVIEWEUR ET DU PROJET}

Guillaume Lamé, stagiaire recherche CSTB-ECP

Projet sur l'écoconception des bâtiments

Objectif: comprendre comment les gens travaillent, comprendre le processus de conception, l'organisation, en se fondant sur l'expérience de personnes expertes

\section{DURABILITE}

C'est quoi un projet durable?

Avez-vous participé à ce type de projets ? Pouvez-vous donner des exemples ?

\section{CONCOURS D'ARCHITECTES}

Intervenez-vous pendant le concours d'architectes?

Quel est votre rôle pendant cette phase ?

Qu'est-ce qui se joue pour vous à ce moment-là ? Quel est l'enjeu ? Qu'espérez-vous retirer de cette étape?

- $\quad$ Faire ressortir les valeurs : sociale, environnementale, économique, culturelle/artistique

Avec qui travaillez-vous?

- A qui êtes-vous lié par contrat ?

- Fréquence des liens avec les autres acteurs ?

Est-ce que vous avez un pouvoir de décision ? D'influence ? Sur quels points ?

- $\quad$ Liste de points d'influence (I) / décision (D) :

- Contraintes reçues

- Identifier les contraintes: schéma "réseau » par type de contraintes: réglementaires, pratiques internes à mon entreprise, économiques, consigne/choix d'un autre acteur

\section{DIFFERENCE ENTRE LES PROJETS « DURABLES » ET LES AUTRES}

Qu'est-ce qui change lors du concours d'architectes quand un projet est présenté comme " durable ", " vert » ? Comment cet aspect se manifeste-t-il ?

Est-ce que vous travaillez différemment ? Si oui, sur quels points ?

- Dans la prise de décision :

- Dans la liste d'acteurs :

- Place de l'exploitant : 
- Place de l'utilisateur:

- Dans les informations utilisées :

- Niveau système (simulations, évaluations, etc.)

- Niveau sous-systèmes (simulation et évaluations partielles)

- Niveau matériaux (FDES, etc.)

- Dans les tâches :

○ Ajouts

○ Modifications

○ Suppressions

Quelles sont les difficultés rencontrées pendant le concours d'architectes dans un projet de conception de bâtiment durable?

\section{OUTILS D’ECOCONCEPTION}

\section{Connaissez-vous des outils d'éco conception ? Pouvez-vous en citer ?}

- Outils connus

En utilisez-vous en phase concours d'architectes ? Pourquoi ?

Qu'est-ce qui améliorerait ces outils ? Qu'est-ce qui renforcerait leur utilisation ?

- Segmenter : interface / mobilisation / usage (facilité) / utilité

Comment intégrez- vous le critère environnemental dans votre pratique ? Comment renforcer cet aspect?

Plus précisément, utilisez-vous l'Analyse de Cycle de Vie (ACV) ?

- Quand?

- Pourquoi, dans quel but?

- Comment inciter à son utilisation (aides, contraintes, formation, éco-conditionnalité...) ? Dans l'idéal, qu'en feriez-vous?

\section{Utilisez-vous la maquette numérique (BIM) ?}

- De quelle manière ?

- Comme support de communication ?

\section{FIN}

Avez-vous quelque chose à ajouter? 